\title{
Evening Primrose Oil
}

National Cancer Institute

\section{Source}

National Cancer Institute. Evening Primrose Oil. NCI Thesaurus. Code C72199.

An oil extracted from the seeds of the plant Oenothera biennis, a North American native biennial branching shrub with small yellow flowers. The oil contains the fatty acids linoleic acid and gamma-linolenic acid (GLA), a rare essential fatty acid. 